\title{
Lords blast red tape in animal experiments
}

Natasha McDowell, London

Britain's system of regulating animal experiments - one of the toughest in the world - has become far too bureaucratic, says a report due to be released by a House of Lords select committee this week.

The Lords charge that current government funds for researching alternatives to animal experimentation are "meagre", saying that more should be done to promote such methods.

Calling animals "highly imperfect models", but acknowledging the necessity of their continued use in research, the committee also recommends that the public should get more information about what animal experiments are done, and why.

The report, which was written by the Select Committee on Animals in Scientific Procedures, advocates reducing the length of the forms needed to acquire a typical licence for animal experimentation from a minimum of 40 pages down to about 10 pages.

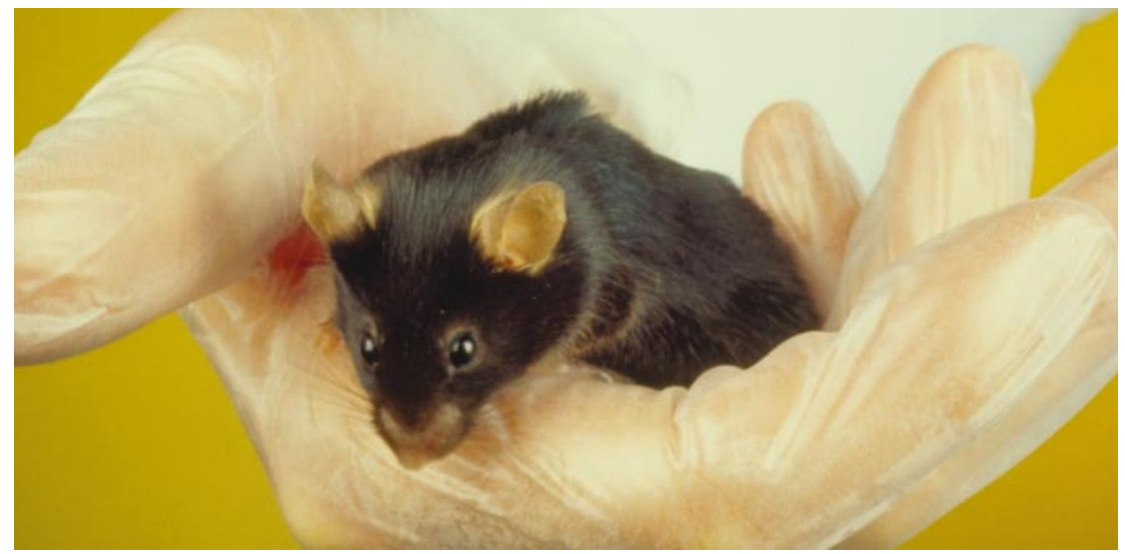

A stronger search for alternatives to animal experimentation is being urged by a House of Lords study.

"There is too much bureaucracy, which hampers scientific research and can even harm animal welfare," says Lord Smith of Clifton, a professor of politics and the committee's chairman. He adds that the Home Office's

\section{US labs bemoan lack of stem cells}

\section{Kendall Powell, Washington}

A year after President Bush publicly wrestled with how best to regulate the use of human embryonic stem cells in research, the availability of approved cell lines remains tightly constrained, US biologists say.

Wendy Baldwin, deputy director of extramural research at the National Institutes of Health (NIH), told the President's Council on Bioethics on 11 July that "in excess of two dozen" such cell lines are characterized and available for research. But this number does not tally with what researchers actually have to hand. Most contacted by Nature put the figure closer to five or six.

Last August, Bush restricted research to cell lines already in existence (see Nature $412,665 ; 2001)$. Later that month, the government said that the NIH had identified

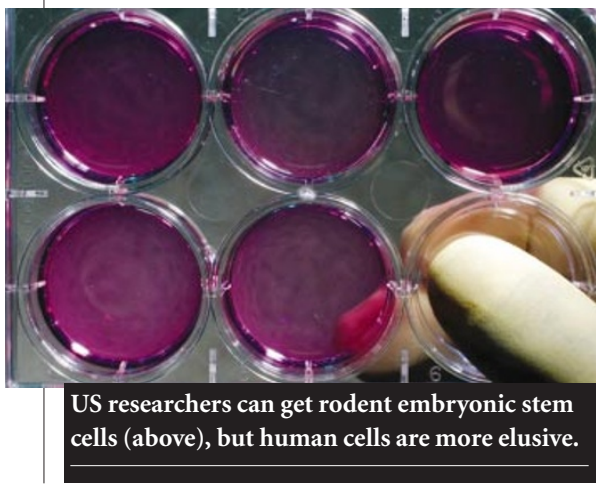

64 eligible cell lines and would establish a registry to aid their distribution to researchers. The registry now lists 78 cell lines from 14 sources in 6 countries.

But most of the lines have not been characterized or tested for long-term growth in the lab. Others are duplicate lines or require company-approved collaboration for access. "There is no lab that works with more than half a dozen of these lines," says Ali Brivanlou, an embryologist at Rockefeller University in New York.

NIH molecular biologist Ron McKay, whose work with mouse embryonic stem cells has produced functional transplanted neurons (J.-H. Kim et al. Nature 418, 50-56; 2002), also estimates that only about five cell lines are ready for use by US researchers. Far more cell lines will be needed to pursue therapies of the future, biologists contend.

Researchers face several hurdles in obtaining lines that the NIH regards as available - import permits are often required, fees of about $\$ 5,000$ per line must be paid, and, most awkwardly, deals have to be struck on intellectual property rights over any derived invention.

In a bid to speed up the flow of cells into the laboratory, the NIH has distributed \$3.5 million in grants to companies that hold the lines to fund their distribution and characterization, as well as to provide relevant training for researchers. http://escr.nih.gov

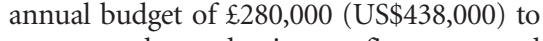
promote the reduction, refinement and replacement of animal experiments is "hopelessly inadequate". The committee calls for moremoney and a new national centre to serve as a focus for this work.

It is not unusual for select committee reports to gather dust in London after publication, but researchers are optimistic that this latest document will generate a response from the government - especially given the depth of the inquiry that preceded it, the government's strong public support for science, and the trouble that scientists are currently experiencing with animal regulations.

Biologists welcomed the committee's call for less arduous regulation. "It is right that the public has assurance of high standards," says Richard Morris of the University of Edinburgh, who uses transgenic mice to develop models of Alzheimer's disease, "but scientists doubt the necessity for regulation to be accompanied by such cumbersome bureaucracy."

Morris says that because of the regulations it is currently "almost impossible" for biomedical researchers in Britain to collaborate with foreign scientists "without flying them in months ahead to sit examinations and secure licences".

But Gill Langley, a biologist who works as a scientific adviser to the Dr Hadwen Trust for Humane Research in Hitchin, north of London, says that the Lords should have focused more strongly on the need to find alternatives to animal experiments. She says that the committee should have proposed a centre dedicated entirely to replacing animals, akin to the European Centre for the Validation of Alternative Methods in Ispra, Italy.

The report also observes that the inclusion of all transgenic animals in government statistics on animal experiments whether they are actually being experimented on or not — is artificially inflating these statistics. 